\title{
AN ANALYSIS OF STUDENTS' INTEREST OF READING ENGLISH NOVEL IN FACULTY OF LETTERS MUSLIM NUSANTARA AL-WASHLIYAH UNIVERSITY
}

\author{
Rezky Khoirina Tarihoran ${ }^{1}$, Ratna Sari Dewi ${ }^{2}$ \\ ${ }^{1}$ Muslim Nusantara Al-Washliyah University \\ ${ }^{2}$ Muslim Nusantara Al-Washliyah University \\ ${ }^{1}$ rezkykhoirinatarihoran@umnaw.ac.id, ${ }^{2}$ ratnasaridewi@umnaw.ac.id
}

\begin{abstract}
This research was aimed to find out how the condition of students' interest in reading English novels in Faculty of Letters, Muslim Nusantara University Al-Washliyah. As a student majoring in English Literature, reading novels is one of the activities that must be carried out because most of the subjects given are closely related to centrality, one of which is an English-language novel. This research was conducted at the fifth semester students of the Faculty of Literature at Muslim Nusantara University AlWashliyah. This research used a qualitative descriptive method. The instruments used were observation and interviews. Based on the results of the study it was found that the condition of students' interest of reading English novels in Faculty of Letters, Muslim Nusantara Al-Washliyah University is very poor.
\end{abstract}

Keywords: Analysis, Reading, Novel

\section{INTRODUCTION}

Reading is the most important activity in the teaching and learning process. Meanwhile, Indonesia is one of the countries that has a low reading interest. In fact, reading should be one of the skills that every student must possess. Harmer (1998: 70) as cited in Parmawati, A., \& Yugafiati (2017) states that, reading is an incredibly active occupation. Reading is an activity informed by the apprehension of images, shapes, patterns, and rhythms, which come to be recognized through repeated encounters and remembered forms; the meanings that are made in reading are in excess of the meanings that arise from the interpretation of written language (Lorange, 2014: 30) as cited in (Parmawati, 2018). Reading is the activity of receiving, analyzing, and interpreting which is done by the reader to obtain the message to be conveyed by the writer in the writing media. Reading activities include reading aloud and silent reading. Reading aloud is a reading activity that is done by reading out loud in public. While the activity of silent reading in is the activity of reading that is done silently and carefully carried out to understand and comprehend the intent or purpose of the writer in written media. By reading we can more quickly discover the latest developments, by reading also one's curiosity will increase rapidly.

The role of interest occupies the most decisive position besides the ability of students to read. Interest has a strong driving force in the realization of an activity. Students' interest in reading arises from the curiosity of students understanding or obtaining information from their environment. How good and interesting the contents of the reading text, but if the reader is indifferent, then reading activities is not possible. Great interest in its influence on learning, because if the learning material learned is not in accordance with the interests of students then there is no attraction for him. Learning material in every level of education in Indonesia does 
not escape from teaching materials in language and literature. Understanding the material starts from school to university. But student interest in appreciating literary works is still lacking. This factor may occur because students do not enjoy reading activities and they have less interest in literary books such as poetry, prose, drama or novels. As technology develops rapidly, they prefer to spend their time with relatively new activities, such as surfing the internet, enjoying music or films. Students are more interested in holding mobile phones, tablets, laptops than reading books, especially literature books, so interest in reading novels is very weak.

The novel is a long prose that contains a series of stories of a person's life with those around him and accentuates the character (character) and nature of each actor (Henry, 2008). The novel consists of chapters and certain sub-chapters according to the story of the story. For English literature students reading novels is very important. Because almost half of the courses are related to literary works, especially novels. Novels in English are preferred over Indonesian novels. It is therefore expected that literary students can increase their interest in reading novels, especially those in English.

Reading novels is one of the most fun and effective ways to hone skills in English. When we read novels of course we will get a lot of new vocabulary and various sentence structures that are diverse. Most students read literary works because with the intention to do the work. That is the reason why most students remain less interested in reading English novels.

With the statement above, this research was carried out to find out the condition of students' interest of reading English novels in Faculty of Letters, Muslim Nusantara Al-Washliyah University.

\section{METHOD}

This research was conducted at the English Literature Study Program, Faculty of Literature, Muslim Nusantara University Al-Washliyah Medan. It used descriptive qualitative method that has purpose to describe and help the reader know what is happening in the environment under observation, what is the viewpoint of participants who are in the background of the research, and what kind of events or activities that occur in the research background (Emzir, 2012). The instruments used for collecting data in this research are:

1. Observation

Observation is an activity of paying close attention to the object of research. In addition, the activity of observation aims to record every situation that is relevant to the purpose of the study. This research uses participatory observation technique which means the researcher is present and involved in the midst of the activity.

2. Interview

Activities in the form of two-way dialogue conducted by researchers to obtain information from the object of research are also called interviews. This research used the unstructured planned interview method, that is, the interviewer prepares a plan and prepares the material but is not detailed according to a specific format (Yusuf, 2005).

\section{RESULTS AND DISCUSSION}

\section{Results}


Based on the results of the interview, it was found that students of Faculty of Letters, Muslim Nusantara University have a very low interest in reading English novels. 7 out of 11 students stated that they do not enjoy the reading activity, let alone in foreign language like English. There were many different reasons that were mentioned by the respondents regarding the problem, some of them are that they do not have much time to read, they do not have adequate range of vocabularies, they do not like to read imaginative stories, they prefer watching movies, and it is too bothersome to read physical book.

\section{Discussion}

As a student of English literature major, reading an English novel is mandatory. If it is not fulfilled, then it will lead to a more serious problem. The purpose of studying literature is to have an understanding of literary world, so that it can be applied and contribute to the real life and society. If the students do not have such an understanding, they will not be able to serve the purpose.

According to researchers, the limited mastery of vocabulary is the most responsible factor for this. Students are not accustomed to reading and understanding in English. Based on observations, when faced with difficult texts, these students do not feel the need to try to digest them themselves and hand them over to translation tools that can be easily accessed on the internet. Students also comprehend these difficult sentences in Indonesian. As a result, they are not accustomed to using the language they are learning. In this case, they will not gain anything from studying in English literature major, neither the English language nor the literature.

\section{CONCLUSION}

The condition of students' interest of reading English novels in Faculty of Letters, Muslim Nusantara Al-Washliyah University is very poor. Lecturers need to find a better approach for the students, so that they will be able to enjoy reading English novels better. Students need to pay more attention and rely on their own ability rather than technology.

\section{ACKNOWLEDGMENTS}

Alhamdulillahirrabbilalamin. All praises and thanks be to Allah SWT who has granted us this ease to complete this research. With all sincerity, the authors thank those who have helped us completing this research :

1. Mr. Dr. Hardi Mulyono, SE, M.Ap., as the Rector of Muslim Nusantara Al-Washliyah University

2. Mr. Dr. H. Firmansyah,M.Sc., asthe Vice Rector I of Muslim Nusantara Al-Washliyah University

3. Mrs. Dr. Hj. Risnawaty, M.Hum., as the Dean of Faculty of Letters at of Muslim Nusantara Al-Washliyah University

4. Mrs. Ir. Ernita,M.P.Ph.D., as the chairman of LP2M Muslim Nusantara Al-Washliyah University

5. All staff of LP2M who have helped us completing this research.

We sincerely hope that this research is useful for the readers and contributes to the education world. 


\section{REFERENCES}

Emzir, M., \& Pd, M. (2012). Metodologi Penelitian Kualitatif Analisis Data. Jakarta: Raja Grafindo.

Henry, T. G. (2008). Membaca Sebagai Suatu Keterampilan Berbahasa. Bandung: Angkasa.

Parmawati, A., \& Yugafiati, R. (2017). Using Authentic Material To Improve Students'reading Interest (A Classroom Action Research In The Second Semester Students Of Stkip Siliwangi Bandung). Eltin Journal, Journal Of English Language Teaching In Indonesia, 5(1), 1-8.

Parmawati, A. (2018). The Study Correlation Between Reading Habit And Pronunciation Ability At The Second Grade Students Of Ikip Siliwangi. Eltin Journal, Journal Of English Language Teaching In Indonesia, 6(1), 46-52.

Yusuf, A. M. . (2005). Metodologi Penelitian: Dasar-Dasar Penyelidikan Ilmiah. Padang: Unp Pres. 